\title{
INSERÇÃO DE ESTUDANTES INDÍGENAS NA UNIVERSIDADE PÚBLICA BRASILEIRA A PARTIR DA PRODUÇÃO TEXTUAL
}

\author{
THE INCLUSION OF INDIGENOUS STUDENTS IN PUBLIC \\ UNIVERSITIES THROUGH TEXT PRODUCTION
}

\author{
Umberto Euzebio' \\ Eduardo Melo Rebouças ${ }^{2}$
}

\begin{abstract}
RESUMO: O convênio FUB/FUNAI foi firmado em 2004 para formar profissionais indígenas, porém os ingressantes por esse sistema enfrentam inúmeros problemas, dentre eles, as dificuldades de leitura e escrita. Neste trabalho a língua foi considerada uma atividade interativa sociocognitiva, um meio para a açăo entre participantes que estâo inseridos em um determinado contexto sócio-histórico. Nessa perspectiva, o texto deve ser visto como um processo de construçăo de sentidos. Assim, o objetivo deste trabalho foi avaliar a prática da Produçâo Textual por estudantes universitários indígenas e sua contribuiçăo para o entendimento e enfrentamento da realidade acadêmica. Como metodologia, foram propostas reflexōes contextualizadas quanto à cultura e à área específica de formaçấo de cada estudante. Dessa forma, produziram um texto sobre pertencimento e uma resenha de um texto de suas respectivas áreas, passando por várias versōes, a partir de feedback textual-interativo. Fundamentados na concepçâo dialógica e sociocultural de língua, texto e gênero, foi trabalhada a produçâo a partir da familiarizaçâo da linguagem científica em oposiçâo ao senso comum como exercício acadêmico. Essa prática proporcionou desenvolvimento de habilidades de leitura e escrita e promoveu interaçăo e inclusăo dos indígenas na Universidade.
\end{abstract}

Palavras-chave: produçăo textual; indígena; gênero textual; inclusăo; educaçăo superior.

ABSTRACT: The agreement FUB/FUNAI was signed in 2004 to train indigenous professionals. However, students of this system face innumerous problems, such as reading and writing difficulties. Within this work, language was considered to be an interactive socio-cognitive activity, a means for action between participants who are inserted in a determined socio-historical context. In this perspective, the text must be seen as a process of constructing meanings. Therefore, the objective of this work was to evaluate the practice of text production by indigenous undergraduates and its contribution to the understanding and confrontation of the academic reality. As methodology, contextualized reflections regarding the culture and specific training area of each student were proposed. In this way, they produced a text about belonging and a

Professor Doutor no Programa de Pós-Graduaçăo em Desenvolvimento, Sociedade e Cooperaçăo Internacional da Universidade de Brasília.E-mail: umbertoeuz@gmail.com.

Graduado em Letras e estudante no Programa de Pós-Graduaçăo em Linguística da Universidade de Brasília. E-mail: eduardomelo.reb@gmail.com. 
review about a text in the students' respective areas, going through various revisions, from textual-interactive feedback. Based in a dialogic and sociocultural conception of language, text and genre, the production was worked on starting from a familiarization with scientific language in opposition to common sense as an academic exercise. This practice provided the development of reading and writing skills and promoted an interaction and inclusion of the indigenous students at the University.

Keywords: text production; indigenous; text genre; inclusion; higher education.

\section{INTRODUÇÃO}

Nas últimas décadas, o governo brasileiro tem orientado suas políticas públicas no sentido de promover açōes que resgatem dívidas sociais e históricas com os povos originários. Assim, o movimento indígena brasileiro inicia e incentiva a inclusâo de seus jovens nesse processo como forma de fortalecimento das lutas de mais de 220 etnias existentes no território nacional (BANIWA, 2006). Essa necessidade é justificada para além da questăo inclusiva, pois, segundo Jacobi (2005), nâo existem representantes indígenas para defender suas causas, uma vez que entre eles năo há formaçăo de profissionais capacitados que venham a ocupar cargos em que há necessidade de formaçăo acadêmica específica. Diante deste contexto, foi firmado, em 2004, um convênio entre a Fundaçāo Nacional do Índio - FUNAI e a Fundaçâo Universidade de Brasília - FUB para formar profissionais indígenas em nível superior na Universidade de Brasília - UnB. Muitos desses estudantes, sobretudo da regiăo norte, concluíram a Educaçâo Básica em língua indígena, uma vez que, de acordo com a Lei de Diretrizes e Bases - LDB, em seu artigo 42, "é assegurado às comunidades indígenas a utilizaçâo de suas línguas maternas e processos próprios de aprendizagem", e no artigo 78:

O Sistema de Ensino da Uniâo [...] desenvolverá programas integrados de ensino e pesquisa, para oferta de educaçăo escolar bilingue e intercultural aos povos indígenas, com os seguintes objetivos:

I - proporcionar aos índios, suas comunidades e povos, a recuperaçăo de suas memórias históricas; a reafirmaçăo de suas identidades étnicas; a valorizaçăo de suas línguas e ciências;

II - garantir aos índios, suas comunidades e povos, o acesso às informaçóes, conhecimentos técnicos e científicos da sociedade nacional e demais sociedades indígenas e năo-índias. (BRASIL, 1996)

Quanto à questăo financeira e ao ensino superior, especificamente no artigo 79, é afirmado:

A Uniâo apoiará técnica e financeiramente os sistemas de ensino no provimento da educaçấo intercultural às comunidades indígenas, desenvolvendo programas integrados de ensino e pesquisa.

‘§3№ que se refere à educaçăo superior, sem prejuízo de outras açôes, o atendimento aos povos indígenas efetivar-se-á, nas universidades públicas e privadas, mediante a oferta de ensino e de assistência estudantil, assim como de estímulo à pesquisa e desenvolvimento de programas especiais. (BRASIL, 1996)

E, no mesmo sentido, no artigo 48 do Estatuto do Índio, "estende-se à populaçăo indígena, com as necessárias adaptaçōes, o sistema de ensino em vigor no país" (BRASIL, 1973). 
Essa política de atuaçăo se fundamenta na valorizaçăo de saberes e tradiçôes dos indígenas inseridos nas demais formas de conhecimento e práticas da Universidade, e na consolidaçăo de uma educaçăo indígena com base nos princípios da especificidade e interculturalidade (EUZEBIO et al., 2012; MOURA; MAKIIUCHI; EUZEBIO, 2014).

Com a característica comum de apresentarem deficiências na formaçăo básica, os problemas enfrentados pelos estudantes indígenas, ao ingressarem no meio acadêmico, envolvem dificuldades, entre outras, de leitura e produçăo de textos, autocrítica negativa em relaçâo às suas capacidades de compreender a língua portuguesa, discriminaçâo, exclusâo e preconceitos étnicos no ambiente da universidade. Nesse cenário, para uma inclusăo e acolhimento efetivos, o ponto de partida para uma prática educacional e educativa deve combinar, assim como apontam Almeida Filho e Cunha (2007) com relaçáo aos estrangeiros, eventos macro e micro da realidade social desse segmento populacional (nesse caso os indígenas), incluindo a sua trajetória de vida à nova realidade.

Assim, com relaçâo ao indígena:

[...] o sistema escolar em que se insere a sala de aula de português muitas vezes pouco tem a ver com a cultura de aprender original dos alunos. Os índios têm seus processos tradicionais voltados para a reproduçấo do conhecimento e socializaçăo, sendo que esses processos săo específicos de cada grupo. Na tradiçấo indígena, o conhecimento é essencial à sobrevivência e é geralmente compartilhado por todos. As crianças indígenas săo educadas para a vida com a experimentaçăo e participaçấo nos diferentes eventos da comunidade. Ignorando isso, muitas vezes as escolas inseridas nas comunidades indígenas sâo modeladas sob a ótica distorcida que, mesmo entre os brasileiros lusofalantes, provoca exclusăo. Essa escola traz consigo práticas de letramento quase sempre estranhas à tradiçăo cultural das comunidades indígenas. Com elas, săo introduzidas práticas sociais que também sâo novas e que, por năo serem monitoradas, podem causar deslocamento cultural e perda da língua minoritária. Ainda assim, aprender o português é uma forma de resistência (CUNHA, 2007, pp. 59-60).

De acordo com Cajueiro (2006), o Conselho Nacional de Educaçăo sugere existir no Brasil em torno de 5.000 estudantes indígenas universitários, entre formados e formandos. Contudo, năo há evidências sistemáticas que confirmem a presença desses estudantes no ensino superior. Esse número poderá estar superestimado, porém, náo se descarta a possibilidade, uma vez que tem sido frequente a afluência de estudantes indígenas na educaçăo superior a partir do suporte de bolsas fornecido até pouco tempo atrás pela FUNAI, com o objetivo de garantir, no quesito financeiro, a permanência desses estudantes, cuja responsabilidade a partir de agora se tornou do Ministério da Educaçăo - MEC. Assim, Linhares e Silva afirmam que:

A crescente procura pelos cursos superiores por parte dos indígenas justificase principalmente pela articulaçăo de seus movimentos juntamente com suas comunidades na busca pela melhoria da qualidade de vida, na defesa de seus direitos e territórios e na preservaçáo de suas diversidades culturais. Ainda que a procura tenha aumentado, o acesso dos índios na universidade ainda é muito baixo. 0 mais recente censo educacional realizado em 2008 pelo INEP (Instituto Nacional de Estudos e Pesquisas Educacionais Anísio Teixeira), do Ministério da Educaçăo, mostra que das 2.985.137 de vagas de ensino superior oferecidas pelas 2.252 instituiçóes brasileiras, 1.093 foram destinadas aos índios, o que representa $0,03 \%$ do total. Essas vagas foram disputadas por 1.713 inscritos. Destes, somente 282 conseguiram ingressar. Além disso, a evasăo é outro problema nessa equaçáo 
que separa índios da universidade. De acordo com o Censo, apenas 13 conseguiram se formar (LINHARES; SILVA, 2011, n.p.).

Diante dos desafios impostos à educaçăo superior indígena, é necessário refletir sobre as açōes que podem contribuir com a sua melhoria, tanto para o alcance dos objetivos educacionais quanto para atender as necessidades e particularidades do público alvo a quem se destinam as práticas educacionais. Nessas circunstâncias, com este trabalho buscamos contribuir para as discussōes no âmbito da temática: inovaçôes metodológicas para uma prática docente inclusiva.

Dessa forma, foi necessário desenvolver metodologias diferenciadas para atender exclusivamente a esses estudantes, uma vez que a inovaçâo educacional pode ser vista como uma açâo multidimensional que abarca, em seu contexto, aspectos cognitivos, afetivos, culturais, tecnológicos, sociais, éticos, políticos, entre outros. Porém, a inovaçâo requer o planejamento, a intervençâo, a sistematizaçâo, a avaliaçăo, a integraçăo de pessoas, sendo, por esses motivos, conotada năo como uma açăo neutra, mas intencional e persistente num contexto singular (CARBONELL, 2001; FARIAS, 2006).

Seguindo esse raciocínio, foi oferecida na Universidade de Brasília - UnB uma disciplina específica de Oficina de Leitura e Produçâo de Texto, exclusivamente para estudantes indígenas.

A proposta de trabalhar com o texto surgiu com base na concepçâo da Linguística Textual de que o processamento textual ocorre simultaneamente em todos os sentidos e de forma holística. Sobre a Linguística Textual, Koch (2014, p. 12) afirma que "Seu objeto central é o texto enquanto processo, enquanto atividade sociocognitivo -interacional de construçăo de sentidos". Para Geraldi (2011, p. 42), "é muito mais importante estudar as relaçóes que se constituem entre os sujeitos no momento em que falam do que simplesmente estabelecer classificaçôes e denominar os tipos de sentenças". Nesse raciocínio, tivemos a preocupaçăo de trabalhar a produçáo textual a partir das necessidades na universidade, sem, no entanto, deixar de contextualizar, assegurando a história, a cultura e a origem da cada estudante indígena. Outra justificativa para se trabalhar com o texto vem dos resultados de trabalhos realizados no curso de Licenciatura Intercultural Indígena na Universidade Federal de Goiás, em que as pesquisadoras afirmam que:

[...] a leitura e escrita enquanto habilidades básicas na sociedade indígena têm sido vistas como competências cada vez mais importantes para assegurar por meio do registro a cultura material e imaterial dos povos indígenas ágrafos. Outro processo importante já ocorre na produçáo de material didático-pedagógico e de livros de literatura, incluindo ainfantil e infanto-juvenil. Constitui-se, portanto, a apropriaçăo da cultura do Outro (a sociedade letrada) a favor das singularidades culturais que caracterizam cada povo indígena no Brasil. Assim, o diálogo intercultural surge como básico na educaçáo escolar em países como o Brasil, caracterizado pelo multiculturalismo (SILVA; LIMA, 2016, p. 102).

A pesquisa, realizada entre 2014 e 2015, consiste em um estudo que expóe e discute os desafios da inclusâo de estudantes indígenas na UnB, partindo de açấo metodológica participativa na perspectiva sociocultural. Foi avaliada a metodologia e a prática da Produçăo Textual por universitários indígenas e sua contribuiçăo para o entendimento e enfrentamento da realidade acadêmica em que estăo inseridos. Para 
tanto, o presente trabalho foi dividido em sequências com a identificaçáo do público alvo, a comunidade indígena da UnB; língua, texto e gênero; metodologia e reflexóes metodológicas e consideraçóes finais.

\section{CARACTERIZAÇÃO DA COMUNIDADE INDÍGENA UNIVERSITÁRIA ESTUDADA}

A inserçâo de indígenas na educaçâo superior vem dos movimentos indígenas na luta da conquista de espaços nessas instituiçôes a partir dos avanços no ensino básico, conforme observado por Amado et al. (2011), indígena da etnia Terena. Os autores destacam também a importância de implantar as políticas públicas partindo da complexidade de visóes e autenticidade de cada povo, a fim de melhorar o acesso e a permanência desses grupos na universidade.

Nesse sentido, Sousa (2009) ressalta que o aumento da busca por formaçâo superior por indígenas se dá pela motivaçăo de se ter mais profissionais para inserçâo social e cultural, no intuito de maior preparaçăo para se participar na luta e aquisiçâo da autonomia e sustentabilidade dos povos indígenas sem detrimento da cultura, dos saberes tradicionais e da língua materna.

Tratando-se do convênio FUB/FUNAI, firmado em 16 de fevereiro de 2004, referente ao ingresso de estudantes indígenas a partir da reserva de vagas na UnB, Euzebio et al. (2012) fizeram uma abordagem das principais dificuldades enfrentadas por esses estudantes no processo de inclusăo no âmbito universitário, bem como apontaram algumas possibilidades de se implementar o apoio necessário para eficácia desse método de integraçăo. Por esse convênio, foram ofertadas vagas para apenas alguns cursos de acordo com as demandas das comunidades indígenas e disponibilidade da Universidade. Assim, depois de firmado o convênio FUB/FUNAI, vieram para a UnB estudantes indígenas para os cursos de Agronomia, Ciências Biológicas, Ciências Sociais, Enfermagem, Engenharia Florestal, Medicina e Nutriçăo, de todas as regiōes do país.

$\mathrm{Na}$ UnB, esses estudantes enfrentam vários problemas adaptativos, como a distância dos familiares, a dificuldade de inserçăo acadêmica, por ser muitas vezes alheia e indiferente à presença indígena, a falta de sensibilidade e a incapacidade da universidade para trabalhar com a diversidade de forma inclusiva, além dos problemas financeiros e de moradia, devido ao alto custo de vida no Distrito Federal. Isso foi constatado também em outras instituiçōes.

Através das entrevistas realizadas com os cinco estudantes universitários indígenas, apontamos urgência na criaçâo de programas institucionais de inclusáo e acompanhamento desses estudantes nas universidades brasileiras. Isso deve ser feito por meio de sistemas e mecanismos que permitam a esses estudantes condiçóes de alimentaçăo, transporte, moradia e disponibilidade de material de estudo, com o objetivo de desenvolver e implementar açóes no sentido de zelar náo só pela permanência, mas, principalmente, reconhecimento e legitimidade étnica, cultural e linguística próprias dessas populaçōes. Para tanto, é preciso identificar e compreender as dificuldades enfrentadas por esses estudantes, e propor medidas que permitam superar as dificuldades. Principalmente, é necessário que as estruturas universitárias sejam repensadas para possibilitarem múltiplas linguagens, espaços, conhecimentos e culturas (RUSSO; DINIZ, 2015, p. 63-64).

Além desses fatores, relatos dos estudantes da UnB apontam que ainda ocorrem 
outros problemas, em dimensóes náo necessariamente menos impactantes, como a estigmatizaçáo, sua exclusăo de grupos de estudos, a falta de domínio da linguagem científica, baixo rendimento acadêmico, alto índice de reprovaçăo, alta taxa de desistência e supervalorizaçăo, por parte da Universidade, do aspecto quantitativo para o rendimento escolar, entre outros problemas. Quanto à questăo da sua exclusăo dos grupos de estudo, há necessidade de maior diálogo entre a Instituiçăo e o acadêmico, uma vez que como afirma Lopes:

[...] se a escola é espaço de mediaçăo com os nâo indígenas, entăo, ela deve, acima de tudo, possibilitar conhecimentos que garantam uma relaçáo melhor entre os sujeitos envolvidos. Desse modo, o ensino [...] deve se constituir também dimensăo da ciência, necessária a cada cidadăo no exercício de seus direitos (LOPES, 2015, pp. 255-256):

A problemática também está presente no meio universitário da Universidade Intercultural de Chiapas, conforme estudos de Sartorello (2016, p. 749-750) ao afirmar que se deve repensar epistemologicamente, para que haja uma mpudança nos métodos de organizaçấo do ensino e aprendizagem, incorporando formas mais dialógicas e de ensino participativo, para que se promovam interaprendizagem e colaboraçâo entre os estudantes indígenas e náo indígenas.

Em estudos desenvolvidos na Universidade Federal da Grande Dourados-MS, os autores afirmam que, após o ingresso de indígenas e negros na Universidade, surgem os desafios da permanência, o que também foi constatado na UnB. Para esses mesmos pesquisadores:

Pesquisas apontam que as desigualdades étnico-raciais se sobrepóem às desigualdades econômicas. 0 desenvolvimento de políticas valorativas, voltadas para o reconhecimento da história da cultura afro-brasileira e indígena, poderia ajudar no reconhecimento da importância dessas políticas, tanto por parte daqueles que foram contemplados como na formaçáo de novos aliados no combate às desigualdades étnico-raciais (AGUIAR et al., 2014, p.123).

Porém, em um estudo sobre políticas de açăo afirmativa, de acesso e de permanência de estudantes indígenas universitários, desenvolvido no Rio de Janeiro, constatamos que "[...] o direito ao acesso à universidade năo significa o direito ao ensino superior" (RUSSO; DINIZ, 2015, p. 46).

Em outro estudo desenvolvido na Universidade Estadual de Alagoas, o autor conclui que a pluralidade cultural e étnica demanda do Estado o desenvolvimento de instrumentos para facilitar o intercâmbio cultural entre os povos e para isso deve haver o conhecimento do outro, dando a ele a oportunidade de mostrar suas competências e capacidades para poder gerir o seu próprio destino (TORQUATO JÚNIOR, 2016, p. 161). Nesse sentido, esse mesmo autor destaca que:

Nesse processo, os indígenas têm muito a oferecer na construçăo de um mundo melhor para a humanidade, sendo necessária a construçáo de novas potencialidades e concepçóes para entendê-los dentro de uma perspectiva individual e coletiva. Educaçăo e diversidade cultural devem andar de máos dadas pelo caminho do progresso da humanidade, sem a presença de ideias que retardem o crescimento e maior envolvimento dos diferentes tipos sociais. Essas săo consideraçóes importantes inerentes a um povo culturalmente evoluído e consciente de que o respeito mútuo está alicerçado numa relaçấo dialógica (TORQUATO JÚNIOR, 2016, p. 161).

Em experiência na Universidade Federal de Roraima, Santos (2015, p. 59) nos 
relata que, ao implantar o sistema de inclusăo indígena na universidade, năo houve apenas preocupaçáo em oferecer vagas, qualificaçăo profissional e entrada no mercado de trabalho, mas também reconhecimento da importância dos valores éticos e dos princípios humanísticos, comprometendo-se com a formaçăo de massa crítica que seja capaz de construir para as geraçóes o desenvolvimento socioeconômico para melhorar a vida das comunidades étnicas.

Bergamaschi, em seu estudo sobre intelectuais indígenas, interculturalidade e educaçấo, conclui que:

[...] a formaçăo de intelectuais indígenas năo ocorre somente na academia: o intelectual indígena que chega à universidade, em geral emerge e atua em movimentos, na organizaçăo e na afirmaçáo étnica, na luta pelo reconhecimento social, político e cultural, pelos direitos básicos de viver na terra e ter respeitado suas territorialidades, por saúde e por educaçáo. É um intelectual que alia o conhecimento próprio de sua cosmologia, mas que propóe e conduz diálogos interculturais importantes, inclusive pautando caminhos para a educaçăo escolar indígena e năo indígena (BERGAMASCHI, 2014, p. 27).

Em uma dissertaçâo de mestrado em Linguística Aplicada, sobre leitura e escrita para indígenas, defendida na Universidade Federal do Rio Grande Sul, Morelo (2014, p. 145) conclui que planejar atividades com temas que contemplam a questáo da identidade indígena ou outras questōes relacionadas possibilitou o engajamento dos estudantes indígenas no uso de línguas, indicando que há possibilidade de um diálogo intercultural.

Nesta pesquisa, foram considerados apenas os acadêmicos indígenas da UnB que cursaram a disciplina específica de Oficina e Leitura de Produçăo de Textos no período mencionado. Os estudantes em questăo, homens e mulheres, pertencem a diferentes cursos e períodos de ingresso, etnias com procedência, sobretudo das regiôes norte e nordeste do país. Todos esses itens foram considerados para a análise da pesquisa, desde a proposta de trabalho até a análise e discussăo do material produzido. Na Tabela 1 săo apresentados os dados com identificaçáo do período de ingresso, total de estudantes, sexo, curso, etnia, origem e situaçăo atual dos estudantes indígenas do convênio FUB/FUNAI entre 2006/1 e 2013/2.

Tabela 1: Caracterização dos estudantes indígenas do convênio FUB/FUNAI participantes da pesquisa

\begin{tabular}{c|c|c|c|c|c|c}
\hline Ingresso & Total & Sexo & Curso & Etnia & UF & Situação em 2016/2 \\
\hline \multirow{2}{*}{$2006 / 1$} & 1 & F & Nutrição & Piratapuia & AM & Graduada \\
\hline \multirow{2}{*}{$2008 / 1$} & \multirow{2}{*}{4} & F & Agronomia & Wassul-cocal & AL & Graduada \\
\cline { 3 - 7 } & & F & Engenharia Florestal & Baré & AM & Graduado \\
\cline { 3 - 7 } & & F & Nutrição & Tupiniquim & ES & Graduada \\
\hline Ingresso & Total & Sexo & Curso & Etnia & UF & Situação em 2016/2 \\
\hline
\end{tabular}




\begin{tabular}{|c|c|c|c|c|c|c|}
\hline \multirow{3}{*}{$2009 / 1$} & \multirow{3}{*}{3} & $\mathrm{~F}$ & Enfermagem & Baré & AM & Cursando \\
\hline & & M & Engenharia Florestal & Karipuna & AP & Cursando \\
\hline & & M & Engenharia Florestal & Potiguara & PB & Cursando \\
\hline \multirow{2}{*}{$2009 / 2$} & \multirow{2}{*}{2} & $\mathrm{~F}$ & Enfermagem & Pataxó & BA & Cursando \\
\hline & & M & Medicina & Fulni-ô & PE & Cursando \\
\hline \multirow{3}{*}{ 2010/1 } & \multirow{3}{*}{3} & $\mathrm{~F}$ & Enfermagem & Tupiniquim & ES & Cursando \\
\hline & & $\mathrm{F}$ & Engenharia Florestal & Atikum & PE & Cursando \\
\hline & & M & Nutrição & Fulni-ô & PE & Cursando \\
\hline \multirow{7}{*}{$2011 / 2$} & \multirow{7}{*}{7} & $M$ & Agronomia & Suruí-Paiter & $\mathrm{RO}$ & Desistente \\
\hline & & $\mathrm{F}$ & Ciências Sociais & Kariri-Xocó & $\mathrm{AL}$ & Cursando \\
\hline & & $\mathrm{F}$ & Ciências Sociais & Kaxuyana & $\mathrm{AP}$ & Cursando \\
\hline & & $\mathrm{F}$ & Enfermagem & Macuxi & $\mathrm{RR}$ & Cursando \\
\hline & & $\mathrm{F}$ & Engenharia Florestal & Yawanawá & $A C$ & Desistente \\
\hline & & M & Medicina & Pankararu & PE & Cursando \\
\hline & & M & Nutrição & Nukini & $\mathrm{AC}$ & Graduado \\
\hline \multirow{6}{*}{$2012 / 2$} & \multirow{6}{*}{6} & M & Ciências Biológicas & Piratapuia & AM & Desistente \\
\hline & & $\mathrm{F}$ & Enfermagem & Kariri-xocó & $\mathrm{AL}$ & Cursando \\
\hline & & $\mathrm{F}$ & Enfermagem & Kokama & AM & Cursando \\
\hline & & $\mathrm{F}$ & Medicina & Pankararu & PE & Cursando \\
\hline & & $\mathrm{F}$ & Medicina & Ticuna & AM & Cursando \\
\hline & & $\mathrm{F}$ & Nutrição & Ticuna & AM & Cursando \\
\hline \multirow{4}{*}{ 2013/1 } & \multirow{4}{*}{4} & M & Agronomia & Pankararu & PE & Desistente \\
\hline & & $\mathrm{M}$ & Ciências Biológicas & Ticuna & AM & Cursando \\
\hline & & $\mathrm{F}$ & Ciências Sociais & Fulni-ô & $\mathrm{PE}$ & Cursando \\
\hline & & $\mathrm{F}$ & Enfermagem & Potiguara & PB & Cursando \\
\hline \multirow{8}{*}{$2013 / 2$} & \multirow{8}{*}{8} & M & Ciências Biológicas & Atikum & PE & Cursando \\
\hline & & $\mathrm{F}$ & Ciências Biológicas & Fulni-ô & $\mathrm{PE}$ & Cursando \\
\hline & & $\mathrm{F}$ & Ciências Sociais & Baniwa & AM & Cursando \\
\hline & & M & Ciências Sociais & Kokama & AM & Cursando \\
\hline & & $\mathrm{F}$ & Enfermagem & Kariri-xocó & $\mathrm{AL}$ & Cursando \\
\hline & & $\mathrm{F}$ & Enfermagem & Kariri-xocó & $\mathrm{AL}$ & Cursando \\
\hline & & $\mathrm{M}$ & Engenharia Florestal & Ticuna & AM & Cursando \\
\hline & & $\mathrm{F}$ & Medicina & Pankararu & PE & Cursando \\
\hline
\end{tabular}

Fonte: elaborada pelos autores

Nos dados apresentados na Tabela 1, estâo 38 estudantes indígenas, 24 mulheres e 14 homens, distribuídos nos cursos de Agronomia (três homens e uma mulher), Ciências Biológicas (três homens e uma mulher), Ciências Sociais (um homem e quatro mulheres), Enfermagem (nove mulheres), Engenharia Florestal (três homens e três mulheres), Medicina (dois homens e três mulheres) e Nutriçăo (dois homens e 
três mulheres). Dentre as etnias: Atikum, Fulni-ô, Kaimbé, Kariri-Xocó, Pankararu, Pataxó, Potiguara e Wassul-Cocal, procedente dos estados do nordeste, totalizando 18 estudantes; Baniwa, Baré, Karipuna, Kaxuyana, Kokama, Macuxi, Nukini, Piratapuia, Suruí Paiter, Ticuna e Yawanawá com 17 estudantes, da regiăo norte e dois da etnia Tupiniquim vindos do sudeste. Os estudantes de algumas etnias, a maioria do norte, cursaram todo o Ensino Fundamental e Médio em Língua Indígena, outros, apenas o Ensino Fundamental e outros em português, na grande maioria em Escolas localizadas na própria comunidade. Desse total, em 2016, cinco estăo graduados, quatro săo desistentes e 29 estâo cursando.

Foi constatado, por meio de relatos dos estudantes e por observaçăo, que a comunidade universitária classifica-os de forma estereotipada ou mesmo estigmatizada por nâo conhecer a realidade indígena, năo os reconhecendo como tal por nâo apresentarem "estereótipos".

\section{LÍNGUA, TEXTO E GÊNERO}

Toda prática de leitura e produçăo de textos proposta pelo professor traz consigo uma concepçăo de língua. Essa concepçăo guia que atividades com o texto serăo realizadas, tendo em vista os propósitos, as finalidades e o entendimento sobre a relaçāo entre autor, leitor e texto. Assim como Marcuschi (2005), entendemos que a língua é mais que um simples código para a comunicaçăo, é "fundamentalmente uma atividade interativa (dialógica) de natureza sócio-cognitiva e histórica" (MARCUSCHI, 2005, p. 22). Nessa perspectiva, enfocando o uso, a língua é um meio para a açâo entre participantes que estăo inseridos em um determinado contexto sócio-histórico (SCHOFFEN; GOMES; SCHLATTER, 2013, p. 259).

Entendendo a língua como atividade e açâo, o texto também năo deve ser tomado simplesmente como um produto acabado, resultante da organizaçấo de palavras dentro da gramática de uma língua. Como afirma Antunes (2010), tudo o que falamos ou escrevemos săo sempre textos, que funcionam dentro de situaçóes reais de comunicaçăo, nas quais estâo envolvidos, além das unidades lexicais e gramaticais, elementos contextuais e conhecimento de mundo. Schmidt (1978, p. 170 apud Antunes 2010, p.31) define texto como "um conjunto-de-enunciados-em-funçăo".Nesse raciocínio, podemos entender o texto numa perspectiva interativa, dialógica (tomando como referencia o dialogismo bakhtiniano), de modo que năo analisemos o texto como um produto final, mas como um processo de construçăo de sentidos entre leitor e escritor, (interlocutores ativos) por meio do texto, em dada situaçăo comunicativa ou interacional (ROTTAVA, 1999). O texto, afirma Antunes (2010, p. 17), "decorre exatamente dos efeitos conseguidos por meio de cada um de nós, feitos textualmente, e pressupostos contextualmente". Ainda segundo a autora, "[...] compreender um texto é uma operaçăo que vai além de seu aparato linguístico, pois se trata de um evento comunicativo em que operam, simultaneamente, açōes linguísticas, sociais e cognitivas" (ANTUNES, 2010, p. 31).

O dialogismo de Bakhtin, que traz Rottava (1999) como perspectiva para analisar a construçăo de sentidos em leitura e escrita, é, nessa vertente teórica, um princípio constitutivo da linguagem, condiçăo para o sentido, que é estabelecido na interaçăo 
entre sujeitos. Nessa perspectiva, há, portanto, uma interaçăo dialógica entre leitor, escritor e texto, na qual se constroem sentidos. Dessa forma, as atividades com o texto devem levantar situaçōes reais e significativas, entender que o texto é um meio de construçăo de sentidos entre leitor e escritor, que săo, portanto, interlocutores ativos, que possuem propósitos e executam intençôes.

Já entendemos, entăo, que na comunicaçăo e interaçăo entre os interlocutores, sempre nos expressamos por meio de textos, construídos a partir de uma língua e de um contexto. Da mesma forma, tudo o que falamos ou escrevemos, o fazemos por meio de gêneros textuais/ discursivos. Assim, todo texto se organiza dentro de um gênero. Por considerarmos a língua e o texto numa perspectiva social, histórica, cultural e cognitiva, da mesma forma, entendemos que os gêneros constroem-se socialmente e se relacionam com as práticas socioculturais. "Gênero é uma categoria cultural; um esquema cognitivo; uma forma de açâo social; uma estrutura textual; uma forma de organizaçăo social; uma açăo retórica" (MARCUSCHI, 2008, p. 149).

Segundo Bakhtin (2003), enunciamos por meio de gêneros, que săo tipos relativamente estáveis de enunciados, já que possuem conteúdo temático, estilo e construçâo composicional; sâo, portanto, como "modelos", criados e entendidos socialmente. Ainda segundo o autor, existem gêneros discursivos mais simples (primários), que se formam nas condiçóes de comunicaçăo discursiva imediata, como a conversa telefônica e o diálogo cotidiano, e gêneros discursivos mais complexos (secundários), que surgem nas condiçôes de um convívio cultural mais complexo e relativamente mais desenvolvido e organizado, como o artigo científico, o resumo e a resenha, gêneros bastante produtivos no contexto acadêmico. Cabe ressaltar que cada gênero tem sua importância, funçâo e adequaçăo, a depender de cada prática textual e, portanto, de cada prática social; nenhum gênero é melhor que o outro.

Ariqueza ea diversidade dos gêneros do discurso săoinfinitas porque săoinesgotáveis as possibilidades da multiforme atividade humana e porque em cada campo dessa atividade é integral o repertório dos gêneros do discurso [...] Cabe salientar em especial a extrema heterogeneidade [funcional] dos gêneros do discurso, nos quais devemos incluir as breves réplicas do diálogo cotidiano [...], o relato do dia a dia, a carta [...], o diversificado universo das manifestaçōes publicísticas [...] também devemos incluir as variadas formas das manifestaçôes científicas e todos os gêneros literários (do provérbio ao romance de muitos volumes) (BAKHTIN, 2003, p. 262).

Os falantes, nas relaçôes sociais e, consequentemente, no contato com diferentes gêneros, vâo desenvolvendo sua competência metagenérica, que lhes permite agir de forma conveniente nas diversas práticas sociais (KOCH; ELIAS, 2012). A aquisiçăo dos gêneros gera certa autonomia.

[...] instrumentalizado em alguns gêneros, o sujeito é capaz de alçar vôo de forma independente porque desenvolve habilidades que lhe permitem usar a língua nas mais variadas práticas sociais, que săo mediadas pelo gênero (COSTA; FOLTRAN, 2013, p. 25)

No contexto acadêmico, por exemplo, o estudante terá contato com diferentes (e, talvez, novos) gêneros, pouco convencionais em outros contextos de uso da língua. Esse contato se dá a partir de diferentes práticas sociais, sejam elas mediadas pela escrita ou pela fala, e, por conseguinte, possibilita a participaçáo em diferentes práticas de 
letramento. Nessa perspectiva, sâo trabalhados outros gêneros de texto, que, ao se tornarem parte da vida do estudante, contribuiráo para o desenvolvimento de sua competência metagenérica e lhe darăo mais autonomia em sua compreensáo e produçáo textual no meio acadêmico.

Dentro desses gêneros acadêmicos (secundários ou complexos em termos bakhtinianos), as próprias estratégias e exigências com relaçấo às tipologias textuais, tanto nos gêneros orais como nos escritos, săo diferentes. Há, portanto, diferenças superestruturais nos textos acadêmicos (assim como em textos de outra natureza. Cada um possui sua especificidade). A argumentaçâo num artigo científico ou numa resenha se organiza de modo diferente do da argumentaçáo que se pode fazer em mensagens pelo Facebook com amigos, ou em conversas telefônicas com algum familiar. Em quaisquer dos gêneros citados, sâo utilizadas as sequências textuais argumentativas, porém as expectativas e exigências săo outras, o que modifica as estratégias de composiçăo da argumentaçăo. Da mesma forma, as sequências expositivas em uma apresentaçăo de seminário, por exemplo, possuem estratégias, exigências e expectativas específicas.

\section{ANÁLISE E REFLEXÕES METODOLÓGICAS DA PRÁTICA TEXTUAL}

No trabalho, foram envolvidos e avaliados os fenômenos socioculturais e educacionais em que estavam inseridos os acadêmicos indígenas, com abordagens de pesquisa-açăo e pesquisa participante, partindo de açôes dos próprios estudantes como sujeitos do processo (THIOLLENT, 2009). Para a estruturaçăo da disciplina foram utilizadas todas as informaçôes obtidas apresentadas na Tabela 1, além de informaçóes alcançadas a partir de relatos dos estudantes. Devido à grande diversidade de etnias, à procedência, aos cursos e, principalmente, à deficiência na formaçăo básica, foram necessários ajustes específicos para se criar estratégias que pudessem atender as necessidades desses universitários. A partir desses dados, optamos por trabalhar com textos orais e escritos, incluindo leitura, interpretaçấo e discussăo de um texto sobre indígena, produzido por um indígena e outro texto específico para a elaboraçâo de resenhas.

As reflexôes foram embasadas em encontros de duas horas semanais com os estudantes, durante dois semestres letivos. A finalidade desses encontros sempre foi de planejar as atividades principalmente de enfrentamento de barreiras impostas pelo sistema dos organismos institucionais. A estratégia utilizada nesse trabalho foi, inicialmente, partir de um texto com abordagem sobre realidade indígena atual, com o objetivo de levantar discussóes para subsidiar a produçấo de um texto sobre pertencimento e, posteriormente, partir de um texto da área específica de cada estudante para produçăo de uma resenha. Portanto, fundamentadas na contextualizaçăo das vivências e experiências do cotidiano dos estudantes, foram desenvolvidas atividades de discussâo relacionadas com o universo do povo a que pertence cada estudante. De acordo com Fazenda (2015, p. 23), quando a pesquisa atinge uma perspectiva interdisciplinar, nos estimula a extrapolar os limites da academia e invadir a vida das comunidades para maior compreensấo da sociedade em questăo.

Com o objetivo de auxiliar na interpretaçăo dos dados, também foi utilizada a 
proposta do diário de pesquisa durante as análises, seguindo a técnica da escuta sensível de Barbier, a escuta científica/clínica; a espiritual/filosófica e a poética existencial, que juntas constituem a abordagem transversal (BARBOSA; HESS, 2010; BARBIER, 2007).

O processo de pesquisar a interdisciplinaridade demandou uma formaçăo especial na forma de pesquisar, que é a marca de todo esse trabalho, a formaçăo para a escuta sensível - escuta aos seus achados ainda năo revelados (nem muitas vezes a si mesmos), escuta paciente e sensível, a melhor forma de retratar e analisar esses achados, escuta sensível à forma de socializá-los e divulgá-los (FAZENDA, 2016, p. 122).

De acordo Nunes et al. (2009), o nosso ensino é marcado por uma estrutura metodológica que enfatiza a memorizaçăo de informaçōes, nomes, fórmulas, verdadeiros conceitos descontextualizados, longe da realidade dos alunos. Logo, consideramos que o entendimento dos conteúdos das disciplinas, em geral por um olhar que desvenda a sua realidade pelo aspecto científico, possa ser bastante eficaz, a fim de suprimir as deficiências conceituais apresentadas por esses alunos. Essa metodologia constitui-se também "como subjetividade curiosa, inteligente, interferidora, na objetividade com que dialeticamente me relaciono, meu papel no mundo náo é só o de quem constata o que ocorre, mas também o de quem intervém como sujeito de ocorrências" (FREIRE, 2011, pp. 74-75).

Nos encontros iniciais, estudantes de diferentes cursos e de diferentes etnias partiram de reflexóes sobre as questōes da realidade de seu próprio povo, fundamentadas no recorte de texto sobre a educaçăo intercultural. Nesse recorte, produzido por Gersem Baniwa, foram discutidas questôes como estereotipizaçăo do indígena divulgada pela mídia como identidade universal e, contrariamente a essa ideia, é tratada a diversidade indígena (BANIWA, 2010).

As dificuldades dos estudantes náo se resumiram apenas aos aspectos linguísticos ou conceituais, mas também na diferença cultural entre os próprios indígenas e, em particular, no que se refere à interferência desse fator no relacionamento dos indígenas com os nâo indígenas. Esses estudantes, em particular os da etnia Ticuna, na maioria das vezes, somente se relacionam com outros indígenas dessa mesma etnia, devido aos problemas de se expressarem na Língua Portuguesa, fato esse que dificulta a interaçăo.

Quando se direciona o olhar para os aspectos da problemática indígena, percebemos as dificuldades de aplicaçăo do conhecimento estudado, particularmente quando há ocorrência de terminologias específicas em meio às questōes abordadas. Por esse motivo, é tăo necessária a constante fixaçâo e discussâo de textos com temas que possibilitem nâo apenas a escrita, mas também a expressăo oral, promovendo, dessa forma, maior compreensâo e argumentaçâo. É evidente a postura passiva dos estudantes em seu processo de aprendizagem, sendo este somente efetivado quando ocorrem estímulos para a busca da autonomia acadêmica.

Paralelamente, a partir de uma concepçâo sociocultural e dialógica de texto, buscamos propor uma reflexăo do "para que trabalhar com o texto" e trazer práticas de "como trabalhar com o texto", de modo que se promova o desenvolvimento das habilidades de leitura e escrita e a inclusâo do estudante no ambiente universitário, lugar 
onde participará de novas práticas sociais e, consequentemente, de novas práticas de letramento, em que a leitura e a escrita estăo envolvidas. Nessa perspectiva, como afirma Soares (2012, p. 47), letramento é o "estado ou condiçâo de quem năo apenas sabe ler e a escrever, mas cultiva e exerce as práticas sociais que usam a escrita".

Para que os estudantes pudessem acompanhar de forma ativa e participativa, houve contextualizaçâo, năo restrita somente ao ambiente social dos estudantes, mas também à resoluçấo de problemas ou estudos de casos abordando questôes ligadas à problemática do seu cotidiano, como, por exemplo, pertencerem a diferentes cursos, etnias e, no entanto, serem tratados todos iguais como se nâo apresentassem diferenças. Assim, abordar o problema possibilitou a discussâo de situaçôes e contextos que despertaram o interesse desses indígenas para a análise mais ampla e profunda do conteúdo envolvido, relacionando-o na medida do possível de forma transversal e multidisciplinar às outras áreas de conhecimento, como aquelas de cada etnia ou do curso específico de cada estudante.

Durante as discussōes foi trabalhada a questâo dos gêneros textuais, enfatizando a modalidade discursiva oral, porém foi também momento oportuno para se trabalhar as diferenças entre a oralidade e a escrita na produçăo do texto, pois:

"[...] o estudo dos gêneros textuais é uma fértil área interdisciplinar, com atençăo especial para o funcionamento da língua e para as atividades culturais e sociais. Desde que náo concebamos os gêneros como modelos estanques nem como estruturas rígidas, mas como formas culturais e cognitivas de açăo social corporificadas de modo particular na linguagem, temos de ver os gêneros como entidades dinâmicas. Mas é claro que os gêneros tem identidade e eles săo entidades poderosas que, na produçấo textual, nos condicionam a escolhas que năo podem ser totalmente livres nem aleatórias, seja sob o ponto de vista do léxico, grau de formalidade ou natureza dos temas [...] (MARCUSCHI, 2008, pp. 155-156)

A primeira produçăo escrita foi a preparaçăo de uma texto narrativo-dissertativo sobre pertencimento, ou seja, sobre a etnia de cada um, porém fundamentado no texto inicial de Baniwa (2006). Como subsídio para a produçáo da primeira versâo do texto, foi necessário que todos lessem e entendessem o texto indicado. Durante três encontros foram levantadas discussōes com comparaçôes, confrontos e identificaçáo de cada conceito correlacionando com cada etnia. Nesse processo, cada estudante expôs a realidade de seu povo e, ao mesmo tempo, conheceu e percebeu que, apesar de serem todos indígenas, cada um apresentou sua própria identidade. De acordo com Magda Soares:

“[...] as consequências do letramento estăo intimamente relacionadas com os processos sociais mais amplos, determinados por eles, e resultam de uma forma particular de definir, e como transmitir e de reforçar valores, crenças, tradiçóes e formas de distribuiçáo de poder." (SOARES, 2012. p. 76)

Nessa etapa, houve percepçăo das formas de fala e escrita, pois "a língua falada e a língua escrita náo se opóem de forma dicotômica nem săo produçóes em situaçóes polares" (MARCUSCHI, 2008, p. 208). Foram produzidas três versóes do texto escrito, sendo que, para cada uma delas, houve orientaçăo para se perceber o verdadeiro sentido pretendido com o texto, com reescrita.

A refacçāo do texto produzido é parte do próprio processo de produçâo da escrita, 
em que necessariamente ocorreu a releitura e a reformulaçăo de passagens. A cada reescrita ocorreram discussôes com o grupo para uma chamada coletiva de reelaboraçâo. Assim, as formas inadequadas foram ajustadas pelo grupo, momento em que também foi verificada aquisiçăo do conhecimento da realidade da etnia do outro.

Após construírem o texto sobre pertencimento, cada estudante escolheu um texto específico da sua área, de preferência um artigo científico pelo qual tivessem interesse em trabalhar, para ser resenhado. Novamente, partimos de um contexto conhecido pelo estudante e, a partir dele, foi feita leitura e interpretaçăo com estruturaçăo em forma de resumo para posteriormente trabalhar com a resenha. Para essa produçáo, também foram feitas três versóes, porém, de forma náo coletiva, já que os textos eram do interesse específico de um.

Trabalhar com o texto é trabalhar diretamente com o uso da língua em contexto, pois em todo momento que usamos a língua em uma interaçăo, interpretamos e produzimos textos. À medida que somos expostos a diferentes práticas sociais, vamos ampliando nosso repertório de gêneros e aprendendo a construir novos textos. “Possuímos um rico repertório dos gêneros dos discursos orais (e escritos). Na prática, usamo-los com segurança e destreza, mas podemos ignorar totalmente a sua existência teórica [...]" (BAKHTIN, 2003, p. 282). Cabe ressaltar que construímos o texto nâo apenas quando o produzimos (escrevemos ou falamos), mas também quando o interpretamos em uma interaçáo, já que vamos construindo seus sentidos (dialogicamente) e, portanto, construindo o texto, de forma cooperativa, tomando como base o princípio da cooperaçăo, proposto por Grice (1975), na relaçăo entre interlocutores e texto: interlocutor-texto-interlocutor.

As dificuldades de leitura e escrita em Língua Portuguesa e autocrítica negativa em relaçăo às capacidades de compreensâo leitora na língua săo uma problemática enfrentada pelos estudantes indígenas, mesmo por aqueles que tiveram toda a formaçăo básica em português. Dois pontos também devem ser considerados: 1) muitos apresentam lacunas na Educaçăo Básica, devido ao contexto escolar existente nas escolas indígenas de Ensino Fundamental e Médio, no que se refere à estrutura e aos conteúdos; e 2) Alguns possuem o português como L1 (primeira língua) e outros como L2 (segunda língua), o que faz com que a leitura e produçâo textual apresentem características distintas, a depender de cada etnia, já que o contato com o português escrito nas práticas sociais de cada povo ocorre em diferentes graus.

Cabe salientar, entâo, que cada povo, e também cada estudante, possui suas particularidades, que săo diversas, inclusive no que se refere à própria relaçăo com a Língua Portuguesa. Habituou-se, erroneamente, considerar os povos indígenas como um só, sem se considerar a grande diversidade existente entre cada um deles, como aponta Baniwa, filósofo indígena, doutor em Antropologia. Se reconhece os povos indígenas como diversos, é importante atentar sempre para o que isso significa, pois implica em vários aspectos da vida, năo só no campo da filosofia ou da forma de pensar e viver, mas também das formas de conceber a sociedade, cosmologia, os valores, o que é considerado como valor e o que é considerado como năo valor. Isso é absolutamente variante (BANIWA, 2010, p. 35).

Cada indivíduo possui sua identidade, individual, mas em relaçăo direta com o outro e com o meio. Entre outras acepçôes, a identidade refere-se, segundo Hall (2005), a aspectos de pertencimento do indivíduo a um grupo social, étnico, racial, nacionalista 
e, também, linguístico. Há um vínculo entre o "eu" e o meio, ou seja, a identidade se forma subjetivamente por meio da interaçăo do indivíduo nas relaçôes sociais com um ou variados grupos (e com o mundo) e, consequentemente, está em constante (trans) formaçấo. $\mathrm{O}$ autor afirma que à medida que os sistemas de significaçăo e representaçăo cultural se multiplicam, somos confrontados por uma multiplicidade desconcertante e cambiante de identidades possíveis. O contato dos indígenas com novas práticas sociais, textuais e discursivas na UnB permite o contato com novos sistemas de significaçăo e representaçâo cultural, o que nâo provoca uma subtraçăo no que se refere à sua identidade.

O texto também é o lugar das particularidades, tem seu lado social e seu lado individual e essa relaçăo dialógica entre o eu, o(s) outro(s) e o meio constrói nossa identidade, que se manifesta nas nossas práticas textual-discursivas.

Trabalhar com textos escritos nâo significa corrigir a produçăo feita pelo estudante a fim de lhe mostrar seus erros. Entendida nossa concepçăo de língua e de texto, cabe refletir sobre que atividades podem ser realizadas para possibilitar uma produçáo textual adequada, como dar subsídios para que os alunos desenvolvam suas competências de leitura e escrita, como avaliar suas produçôes e, também, como dar um feedback produtivo para o estudante. Trazemos, entâo, discussóes acerca de como trabalhar com o texto, que partem das contribuiçōes da Linguística Textual (ANTUNES, 2010; KOCH; ELIAS, 2012; KOCH, 2014) e da Teoria Sociocultural (PAIVA, 2014) e das experiências obtidas com a disciplina de oficina de texto, específica para os acadêmicos indígenas.

Foi necessário contemplar gêneros com os quais os estudantes têm contato direto na universidade, e têm dificuldades tanto de compreensâo quanto de produçâo. Seguimos a proposta procedimental de sequências didáticas para atividades de escrita, de Dolz; Noverraz; Schneuwly (2004), trabalhando com módulos, a fim de possibilitar um trabalho mais profundo com o texto. Utilizamos uma sequência didática para cada gênero, nesse caso, para a produçăo referente à temática de pertencimento e para a resenha. A estrutura básica da sequência está composta por: apresentaçăo da situaçâo, produçăo inicial, módulos e produçáo final, representado no esquema a seguir, como proposto por Dolz; Noverraz; Schneuwly.

Figura 1. Esquema da sequência didática

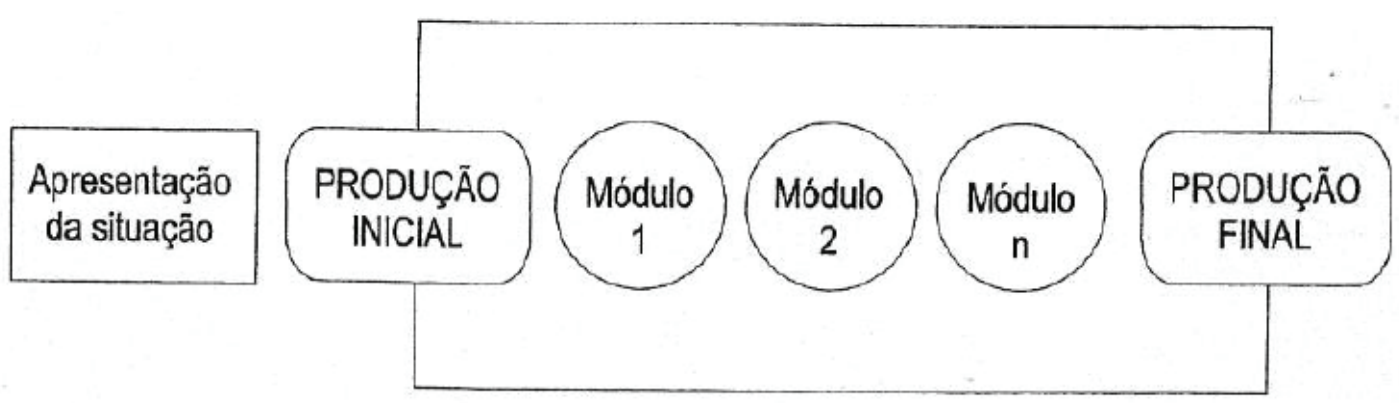

Fonte: DOLZ; NOVERRAZ; SCHNEUWLY, 2004, p. 83.

A sequência didática é, portanto, um conjunto de atividades sistemáticas em 
torno de um gênero (ou mescla de gêneros a depender da proposta e do propósito do trabalho), que busca fazer com que o estudante domine-o, instrumentalizando o aluno e permitindo-lhe escrever de maneira mais adequada em uma situaçăo específica de comunicaçấo. Os módulos sâo as atividades que o professor percebeu, pela produçáo inicial, que necessitam ser desenvolvidas, até chegar a uma produçăo final que supra as expectativas do gênero.

Para a produçáo do texto, o aluno tem de ser exposto aos usos específicos de cada gênero, ou seja, ter acesso a outros textos. O estudante pode náo ter êxito na produçâo de uma resenha se náo souber do que se trata esse gênero, como se efetiva na prática textual, como se organiza, enfim, ele tem de ter acesso a outras resenhas para entender seu funcionamento; consequentemente ampliar sua competência metagenérica, que se adquire nâo com um manual de produçâo textual, mas com o contato e a prática.

A produçăo inicial guia toda a sequência e, dessa maneira, o que se pede deve estar claro, indicando o contexto situacional, os interlocutores previstos e a proposta comunicativa (DELL'ISOLA, 2009). A partir do texto produzido pelo estudante, podemos ver quais săo os pontos fortes e quais podem ser melhorados. Dessa maneira, nos módulos, consegue-se trabalhar com atividades variadas de leitura, interpretaçăo, produçăo e análise do próprio texto, contemplando diferentes níveis, como o conteúdo, a situaçăo, o planejamento do texto, a organizaçáo dos parágrafos e as questóes de coesáo que prejudicam a compreensăo por parte do leitor.

Ressaltamos que, nos módulos, foram contempladas questóes demandadas pelos próprios estudantes, seja pela produçâo inicial, ou seja, elementos observados em seus textos, que poderiam ser trabalhados, seja pelo que eles mesmos tinham interesse em estudar. Constatamos a necessidade de se trabalhar, por exemplo, com a organizaçâo de parágrafos; com as normas para citaçăo (nesse caso as da Associaçâo Brasileira de Normas Técnicas - ABNT), por serem importantes em textos acadêmicos; e com a estrutura do enunciado: questôes de coesăo e coerência, que nấo sâo fenômenos com dependência intrínseca, como afirmam (KOCH; ELIAS, 2012).

Dessa forma, foi identificado e explorado cada ponto dentro dos textos e, no caso de dificuldades comuns/partilhadas, foram criados módulos a serem trabalhados com todo o grupo, e no caso de particularidades, as inadequaçôes e dificuldades foram discutidas individualmente com o aluno ou trabalhadas com apontamentos e comentários no próprio texto produzido, entregue aos estudantes após avaliaçaáo. Depois de discutidas e praticadas as dificuldades apresentadas, foi demandada a reescritura do texto para avaliaçăo. Trabalhando com essa proposta, percebemos que dois pontos devem ser necessariamente ponderados: o papel do professor no processo de construçâo e reconstruçáo do texto e o papel do feedback, além da reflexăo sobre como conferi-lo de forma produtiva.

Tomando como base a teoria sociocultural, embasada nas perspectivas vygotskianas (Paiva, 2014), a aprendizagem é mediada e essa mediaçâo ocorre de formas distintas; a própria linguagem é uma ferramenta de mediaçăo. No âmbito do ensino, o professor funciona como um mediador, que atua na Zona de Desenvolvimento Proximal (ZDP) do aprendiz, ou seja, atua entre o nível de desenvolvimento real e o nível de desenvolvimento potencial, havendo um processo (denominado 'andaime' 
na abordagem vygotskiana) que habilita o aprendiz a "executar uma tarefa".

Ao trabalhar com o texto, também adotamos essa postura teórica e metodológica, sendo o professor um mediador no processo de construçâo de sentidos do texto, dando suporte para que o aluno compreenda pontos que podem ser mais bem elaborados, fazendo-o náo somente compreender suas dificuldades, mas também, dando subsídios para que o aprendiz possa, de fato, trabalhar com seu texto. Ao receber uma produçáo escrita, temos de entender que um texto vai muito além da gramática (ANTUNES, 2010). Segundo Tribble (1996, p.118-134 apud Soares, 2009), o professor pode assumir variados papéis, sâo eles o de leitor ('audiência'. Foco no conteúdo), assistente ('comentarista'. Foco no processo de construçâo do texto), avaliador (foco na produçấo final) e examinador (estabelece uma nota para a produçáo). Essa postura ante o texto do aluno guiará o tipo de feedback ou retorno que o aprendiz receberá. No caso da disciplina, nosso foco esteve no processo de construçâo do texto, em que trabalhamos com a forma e com o conteúdo, dentro das exigências dos textos acadêmicos.

O termo feedback, com o qual trabalha Soares (2009), se refere a um meio de darmos assistência ao desempenho do aprendiz, de modo a auxiliá-lo para que possa avançar na ZDP. Esse feedback tem de ser motivador e fornecer informaçôes que capacitem o aluno a identificar os aspectos de seu desempenho, dando informaçóes acerca de pontos positivos e outros que sâo passíveis de melhoria. Dessa forma, fornecer um feedback é mediar, é trabalhar de modo colaborativo, é dar oportunidades de reescrita, é dar um espaço para elogios e para apontamento de inadequaçóes. Lembrando que náo tem de ser necessariamente escrito.

Soares (2009) apresenta dois procedimentos de correçâo para prover o feedback: a correçâo direta e a correçăo indireta, também chamada de autocorreçâo (mediada), cada uma com seus pontos positivos e negativos. A direta se refere ao paradigma mais tradicional; é quando o professor corrige o texto do aluno já mostrando a forma mais adequada de pontos problemáticos. A correçăo indireta subdivide-se em três: a indicativa (que aponta ou marca inadequaçôes, sem explicaçôes), a classificatória (que aponta ou marca inadequaçóes categorizando-as/classificando-as) e, por fim, a textual-interativa, que promove uma interaçăo entre professor-aluno, seja por meio escrito (um bilhete orientador) ou face a face, momento em que se discute o texto com o próprio aluno/ autor. Cabe lembrar que, assim como afirma Soares (2009, p. 45), "năo há consenso sobre a melhor maneira de tratar o texto do aluno". Tudo dependerá, na verdade, do propósito de trabalho além, das concepçóes teóricas e metodológicas do professor.

Esse retorno ao estudante deve ser intencional e muito bem planejado. O que significa, por exemplo, uma interrogaçăo no texto do aluno? O que significa dizer que a frase está incoerente? Será que o aluno escreveu como o intuito de ser incoerente, rompendo com a funçâo básica de comunicaçáo? Se estiver escrito no texto "estruturar melhor o parágrafo", o aluno conseguirá estruturá-lo da forma desejada? Portanto, cabe ao professor oferecer um feedback com comentários mais pontuais e produtivos, que realmente guiem o aluno para a reescrita de seu texto e que contribuam para o desenvolvimento de competências de escrita. As competências aqui citadas se referem às propostas por Rojo (2009).

Ainda que o foco do trabalho tenha sido o processo de produçăo dos textos, foi 
elaborada uma matriz de referência, Quadro 1, específica para o público em questăo, apenas como parâmetro, para a avaliaçấo final do texto. Desse modo, náo adentramos em discussôes pertinentes à construçâo da matriz (que seria outro foco), já que serviu simplesmente como orientaçăo. A composiçăo final traz a redaçăo construída, finalmente, após as mediaçōes. A partir do texto final, analisamos e constatamos os avanços obtidos ao comparar com a primeira produçăo, seja com relaçăo ao gênero, tipologias, coesâo ou coerência.

Quadro 1: Matriz de referência para avaliação

\begin{tabular}{c|c|c|c}
\hline Categoria & (1) Gênero e Tipologia & (2) Coesão & (3) Coerência \\
\hline \multirow{5}{*}{ Insuficiente } & $\begin{array}{c}\text { Demonstra domínio escasso do } \\
\text { gênero em questão e não aplica } \\
\text { adequadamente as tipologias } \\
\text { necessárias para a construção } \\
\text { desse texto. }\end{array}$ & $\begin{array}{c}\text { Articula as partes do texto } \\
\text { com muitas inadequações e } \\
\text { apresenta repertório limitado de } \\
\text { recursos coesivos. }\end{array}$ & $\begin{array}{c}\text { Apresenta informações e } \\
\text { opiniões desorganizadas e/ } \\
\text { ou contraditórias, que afetam } \\
\text { os sentidos do parágrafo e do } \\
\text { texto como um todo. }\end{array}$ \\
\hline \multirow{5}{*}{ Média } & $\begin{array}{c}\text { Apresenta domínio mediano } \\
\text { do gênero e tipologias a ele } \\
\text { atribuídas. Desenvolve o tema } \\
\text { da maneira esperada para esse } \\
\text { texto. }\end{array}$ & $\begin{array}{c}\text { Articula as partes do texto, } \\
\text { de forma mediana, com } \\
\text { inadequações, e apresenta } \\
\text { repertório pouco diversificado } \\
\text { de recursos coesivos. }\end{array}$ & $\begin{array}{c}\text { Apresenta informações } \\
\text { e opiniões de maneira } \\
\text { relativamente clara e } \\
\text { organizada. Apresenta alguns } \\
\text { problemas de construção de } \\
\text { sentidos durante algumas } \\
\text { partes do texto, que podem } \\
\text { afetar a coerência global. }\end{array}$ \\
\hline \multirow{5}{*}{ Suficiente } & $\begin{array}{c}\text { Apresenta bom domínio do } \\
\text { gênero e tipologias a eles } \\
\text { atribuídos. Desenvolve o tema } \\
\text { da maneira esperada para esse } \\
\text { texto, de forma consistente. }\end{array}$ & $\begin{array}{c}\text { Articula bem ou com poucas } \\
\text { inadequações as partes do } \\
\text { texto e apresenta repertório } \\
\text { diversificado de recursos } \\
\text { coesivos. }\end{array}$ & $\begin{array}{c}\text { Apresenta informaç̃̃es e opiniões } \\
\text { de maneira clara e organizada. } \\
\text { Os sentidos construídos durante } \\
\text { a produção contribuem para a } \\
\text { coerência global. }\end{array}$ \\
\hline
\end{tabular}

Fonte: Elaborada pelos autores

\section{CONSIDERAÇÕES FINAIS}

A estratégia adotada, fundamentada na contextualizaçăo do universo indígena, levou-os para a sua realidade e possibilitou a familiarizaçăo da linguagem científica em oposiçấo ao senso comum como exercício acadêmico. Em conformidade com Marcuschi (2008), podemos constatar que foi possível a efetivaçăo desse processo, por meio de uma gramática do texto, ou reflexiva, sempre contextualizada de acordo com o momento de envolvimento em que o estudante se encontrava. Essa gramática mostra a funçăo de determinado elemento em sua relaçăo textual, sua funçăo dentro do texto. É importante reinvestir nos conceitos estudados em atividades mais complexas. (MARCUSCHI, 2008, p. 79-80) A refaçăo textual se caracteriza como um dos aspectos fundamentais da prática de análise linguística que toma como ponto de partida a produçâo do aluno.

Pode-se trabalhar com todos os aspectos textuais, sejam os relacionados às características estruturais dos diferentes tipos textuais como também os gramaticais que possibilitam a instrumentalizaçăo do aluno no domínio da linguagem escrita. No início da disciplina, os estudantes afirmaram năo saber português, e ter muitas dificuldades 
para ler e escrever. Aos poucos foram percebendo que o texto precisa ser explorado e com isso vâo percebendo suas nuances. No trabalho de compreensâo (oral ou escrita), a perspectiva textual alerta para a necessidade de considerar todos os fatores em jogo (KOCK; TRAVAGLIA, 2007, p. 103-104).

Pela análise dos próprios estudantes indígenas, a produçăo textual somente teve êxito devido ao processo de contextualizaçăo em que foram submetidos para a produçăo, principalmente do texto oral. A escolha do texto contextualizado promoveu interesse e curiosidade, facilitando a discussâo, inclusive no texto final quanto aos aspectos gramaticais, sintáticos, semânticos e pragmáticos, mostrando terem adquirido autoconfiança para os enfrentamentos na vida acadêmica.

A produçâo textual é um instrumento nâo apenas de aprendizado da oralidade e da escrita, mas também um fator de agregaçăo social entre os membros do grupo, e a escolha do texto voltado para a realidade dos estudantes promoveu maior interesse e curiosidade, além de facilitar o processo de discussāo entre os estudantes indígenas.

Foi possível avançar na discussâo acerca do texto produzido quanto aos aspectos gramaticais, sintáticos, semânticos e pragmáticos sem a ideia tradicional ou convencional de "correçāo de texto".

A inclusăo de estudantes historicamente marginalizados consiste em desafio para a reestruturaçâo e a criaçăo de novas estratégias metodológicas e relaçôes de ensino e aprendizagem, o que recupera o ser humano como cerne de todo processo formativo. No intuito de conservar processos de aprendizagens multiculturais, surge a necessidade de desenvolver mecanismos éticos, étnicos e políticos de permanente vigilância para que a universidade nâo se torne instituiçấo colonizadora e ameaçadora do direito dos povos originários de preservarem suas identidades étnicas. 


\section{REFERÊNCIAS}

AGUIAR, M. M; ANDRADE, R.; MARQUES, E. P. S.; ALMEIDA, F. A. Açāo afirmativa e inclusâo etnico-racial: estudo preliminar das políticas de acesso e permanência na Universidade Federal de Grande Dourados entre 2011 e 2013. 0 Social em Questăo, v. 17, n. 32, 2014. pp. 101-126.

ALMEIDA FILHO, J. C. P. de; CUNHA, M. J. C. Projetos iniciais em português para falantes de outras línguas. Brasília: EdUnB, Campinas: Pontes, 2007.

ANTUNES, I. Análise de textos: fundamentos e práticas. Săo Paulo: Parábola Editorial, 2010.

BAKHTIN, M. Estética da criaçăo verbal. Săo Paulo: Martins Fontes, 2003.

BANIWA, G. J. S. L. 0 índio brasileiro: o que você precisa saber sobre os povos indígenas do Brasil de hoje. Brasília: Ministério da Educaçăo. Secretaria de Educaçăo Continuada, Alfabetizaçấo e Diversidade; LACED/ Museu Nacional, 2006.

Educaçăo escolar indígena. Revista FAEEBA - Educaçăo e Contemporaneidade. v. 19, n. 33, 2010. pp. 35-49.

BARBIER, R. A pesquisa-açăo. Brasília: Líber Livro, 2007.

BARBOSA, J. G.; HESS, R. 0 diário de pesquisa: o estudante universitário e seu processo formativo. Brasília: Líber Livro, 2010.

BERGAMASCHI, M. A. Intelectuais indígenas, interculturalidade e educaçăo. Tellus, v. 14, n. 26, 2014, pp. 11-29.

BRASIL. Presidência da República. Lei n. 6.001, de 19 de dezembro de 1973. Dispóe sobre o estatuto do índio. Disponível em: http://www.jusbrasil.com.br/topicos/11722167/artigo-48-da-lei-n-6001-de-19-de-dezembro-de-1973. Acesso em: 27 ago. 2016.

BRASIL. Presidência da República. Lei n. 9.394, de 20 de dezembro de 1996. Estabelece as diretrizes e bases da educaçăo nacional. Disponível em: http://www.planalto.gov.br/ ccivil_03/leis/L9394.htm. Acesso em: 27 ago. 2016.

CAJUEIRO R. Os povos indígenas em instituiçōes de ensino superior públicas federais e estaduais do Brasil: levantamento provisório de açôes afirmativas e de licenciaturas interculturais. Projeto Trilhas de Conhecimento: o Ensino Superior de Indígenas no Brasil, 2006. Disponível em: http://www.trilhasdeconhecimentos.etc.br/educacao_superior_indigena/arquivos/Levantamento\%20de\%20A\%E7\%F5es\%20Afirmativas.pdf. Acesso em 24 set. 2016.

CARBONELL, J. A aventura de inovar: a mudança na escola. 1. ed. Porto Alegre: Artmed, 2002. (Coleçăo Inovaçâao Pedagógica, v. 1)

COSTA, I. B.; FOLTRAN, M. J. (Orgs.). A tessitura da escrita. Sáo Paulo: Contexto, 2013.

CUNHA, M. J. C. Pesquisa aplicada na área de português para falantes de outras línguas: procedimentos metodológicos. In: ALMEIDA FILHO, J. C. P. de; CUNHA, M. J. C. Projetos iniciais em português para falantes de outras línguas. Brasília: EdUnB, Campinas: Pontes, 2007. 
DELL'ISOLA, R. L. P. Gêneros textuais em livros didáticos de língua estrangeira: o que falta? In: DIAS, R.; CRISTOVÂO, V. L. (Orgs.). O livro didático de língua estrangeira: múltiplas perspectivas. Campinas: Mercado das Letras, 2009.

DOLZ, J.; NOVERRAZ, M..; SCHNEUWLY, B. Sequências didáticas para o oral e a escrita: apresentaçăo de um procedimento. In: SCHNEUWLY, B; DOLZ, J. Gêneros orais e escritos na escola. Săo Paulo: Mercado das Letras, 2004.

EUZEBIO, U.; SARAIVA, A. L. R.; MOREIRA, A. L. C. da; CARDIA, F. M. S. dos; LEAL, A. H. H. Migraçāo e transformaçōes sociais de estudantes indígenas decorrentes de açôes afirmativas de inclusăo na Universidade de Brasília. In: Anais do XVIII Encontro de Estudos Populacionais da ABEP, Campinas: ABEP, 2012.

FARIAS, I. M. S. de. Inovaçăo, mudança e cultura docente. 1. ed., Brasília: Líber, 2006.

FAZENDA, I. C. A. Interdisciplinaridade: história, teoria e pesquisa. 18. ed. Săo Paulo: Papirus, 2016.

.; TAVARES, D. E.; GODOY, H.P. Interdisciplinaridade na pesquisa científica. Sâo Paulo: Papirus, 2015.

FREIRE, P. Pedagogia da autonomia: saberes necessários à prática educativa. 43.ed. Sâo Paulo: Paz e Terra, 2011.

GERALDI, J.W. Concepçōes de linguagem e ensino de português. In: GERALDI, J. W. (Org.) 0 texto na sala de aula. 5. ed. Sáo Paulo: Ática, 2011, pp. 32-38.

GRICE, H. P. Logic and conversation. In: Cole, P., Morgan, J. L. (Orgs.) Syntax and Semantics. n. 3, Speech Acts. New York: Academic Press, 1975, pp. 41-58.

HALL, S. A identidade cultura na pós-modernidade. 10. ed. Rio de Janeiro: DP \& A, 2005. JACOBI, R. P. Educaçâo ambiental: o desafio da construçâo de um pensamento crítico, complexo e reflexivo. Educaçăo e Pesquisa, v. 31, n. 2, 2005, pp. 233-250.

KOCH, I. V.; TRAVAGLIA, L. C. A coerência textual. 17. ed. Sâo Paulo: Contexto, 2007.

As tramas do texto. 2. ed. Sâo Paulo: Contexto, 2014.

., Elias, V. M. Ler e escrever: estratégias de produçăo textual. 2. ed. Săo Paulo: Contexto, 2012.

LINHARES, F. M.; SILVA, T. R. da. O cenário indígeno-universitário atual do país. ANAIS DO CONGRESSO NACIONAL UNIVERSIDADE EAD E SOFTWERE LIVRE, v. 2, n. 2, 2011. Disponível em: http://www.periodicos.letras.ufmg.br/index.php/ueadsl/issue/view/172 Acesso em 24 set. 2016.

LOPES, E. T. Ensino-aprendizagem de química na educaçăo escolar indígena: o uso do livro didático de química em um contexto Bakairi. Quím. Nova Esc., v.37, n.4, 2015, p.249-256. MARCUSCHI, L. A. Oralidade e Ensino de Língua: uma questăo pouco "falada". In: DIONÍSIO, A. P., BEZERRA, M. A. (Orgs.). O livro didático de Português: múltiplos olhares. 3. Ed. Rio de Janeiro: Lucerna, 2005.

. Produçăo textual, análise de gêneros e compreensăo. Săo Paulo: Parábola, 2008.

MORELO, B. Leitura e escrita na universidade para estudantes indígenas: princípios e práticas pedagógicas para uma açăo de permanência nos campos das linguagens. 2014. 
188f. Dissertaçăo (Mestrado em Linguística Aplicada) - Instituto de Letras, Universidade Federal do Rio Grande do Sul, Porto Alegre, 2014.

MOURA, L. B. A. de; MAKIUCHI, M. F. R. de; EUZEBIO, U. Educaçăo superior indígena: algumas reflexóes na Universidade de Brasília. In: Zaneti, I. C. B. B. et al. (Orgs.). Programa Conexóes de Saberes em cinco tempos. Brasília: Cidade Gráfica e Editora, 2014, pp. 39-49.

NUNES, S. M. T. et al. O ensino CTS em educaçăo química: uma oficina para professores e alunos do curso de licenciatura em química da UFG. Poiésis Pedagógica. v. 7, 2009, pp. 93-108

PAIVA, V. L. M. O. de. Teoria sociocultural. In Aquisição de segunda língua. São Paulo: Parábola, 2014.

ROJO, R. Alfabetismo(s) - Desenvolvimento de competências de leitura e escrita. In: Letramentos múltiplos, escola e inclusăo social. Săo Paulo: Parábola, 2009.

ROTTAVA, L. A perspectiva dialógica na construçâo de sentidos em leitura e escrita. Linguagem \& Ensino, Vol. 2, n. 2, 1999, pp. 145-160.

RUSSO, K.; DINIZ, E. Políticas de açăo afirmativa e o direito à educaçăo: desafios de acesso e permanência de estudantes indígenas no estado do Rio de Janeiro. Periferia Educaçáo Cultura \& Comunicaçăo. v. 7, n. 1, 2015. pp. 46-65.

SANTOS, Roberto Ramos. Índios e universidade: os caminhos da educaçăo superior indígena na amazônia brasileira - Roraima. Indagatio Didactica, v. 7, n. 4, 2015. pp. 39-61.

SARTORELLO, Stefano Claudio. Convivencia y conflicto intelectual: jóvenes universitarios indígenas y mestizos en la Universidad Intercultural de Chiapas. REMIE, v. 21, n. 70, 2016, pp. 718-757.

SCHOFFEN, J. R.; GOMES, M. S. da; SCHLATTER, M. Tarefas de leitura e produçăo de texto com base na noçăo bakhtiniana de gêneros do discurso. In: Silva, K. A., Santos, D. T. (Orgs.). Português como língua (inter)nacional: faces e interfaces. Campinas: Pontes, 2013.

SILVA, L. G. da; LIMA, S. C. de. Desafios da formaçâo de professores indígenas no Brasil: contribuiçōes geográficas. Revista Interface. v. 11, 2016, pp. 89-104.

SOARES, D. de A. Produçáo e revisăo textual: um guia para professores de Português e de Línguas Estrangeiras. Rio de Janeiro: Vozes, 2009.

SOARES, M. Letramento: um tema em três gêneros. 3. ed. Belo Horizonte: Autêntica, 2012.

SOUSA J. N. R. de Os desafios dos estudantes e das instituiçôes no convênio FUNAI - UNB. 2009, 85 f. Monografia (Especializaçăo em Indigenismo e Desenvolvimento Sustentável) - Centro de Desenvolvimento Sustentável, Universidade de Brasília, Brasília, 2009.

THIOLLENT, Michel. Pesquisa-açăo nas organizaçóes. 2. ed. Săo Paulo: Atlas, 2009.

TORQUATO JÚNIOR, E. Prolind: uma realidade no processo de formaçâo de professores indígenas. Revista de Estudos Linguísticos, Culturais e da Contemporaneidade, n. 18b, 2016. p. 155-163. 